\title{
Prevalence of Hepatitis B Virus infection Markers Among a Working Population in a Coastal City of Yantal, China
}

\author{
Kazunori Seiji', Masaru Takahashi', Osamu Inoue', Shi-Xiong Cai' \\ Mej-Yuan Huang', Takao Watanabe ${ }^{3}$, Toshio Kawai', Tomojiro Yasugi' \\ Jiang-Bin $\mathrm{Qu}^{\mathrm{s}}$, and Masayuki lkeda
}

Three markers of hepatitis B virus (HBV) infection, HBsAg, anti-HEs and anti-HBc, were investigated in the sera from 426 factory workera of both sexes In a coestal clity of Yantai in Chine. The investication showed that the rate of those positive to HBsAg was $25.4 \%(25.9 \%$ in men and $24.6 \%$ in women), and that the rate when two sexes were comblned was highest (i.e., $29.5 \%$ ) at the ages of 208 followed by gradual decrease at higher ages (bolow 20\%). The over-all HBV infection rate as celculated by thase positive to any of the three markers studied was 70.4\%. Comparison wth rates reported in literature Indicated that the rate of $\mathrm{HBsAg}$ positive cases in the present study are probably among the highest values in China, whereas over-all rete of HBV Infection was almost comparable to the values for other provinces. It should be added that other reports on other parts of Shandong Provinces describe HBsAg" prevalence of about $6 \%$. No explenation is currently avallable for the high HBSAg prevalence among the study population. $J$ Epidemiol, $1901 ; 1$ : 11-17.

unti-HBc, anti-HBs, China, HBsAg, HBV

Persistent infection of hepatitis B virus (HBV) is among the known risk factors of primary hepatocellular carcinoma (PHC). Accordingly, increasing attention has been given in public health to the prevalence of the HBV infection with intention for the prevention of this insidious disease ${ }^{-7}$. It is generally understood that the prevalence is higher in many parts of the Asian and Pacific regions than in northern Europe and North Americal.2,4.8-10!. Reports on HBV prevalence in China are also growing in numbers in recent years reflecting the large population, with focus to the areas of high PHC incidence such as Guangxi Province ${ }^{8,7,11-15)}$.

In continuation of seroepidemiological surveys by this study group on HBV infection in East Asia ${ }^{18-18)}$, a study was conducted in a coastal city of Yantai in Shandong Province, China, the area where there still exists a paucity of duta on HBV infection.

\section{MATERIALS AND METHODS}

Sera. In 1991, the survey was conducted in a porl city of Yantai in Shandong Province. on the north coast of the Shandong Peninsula, as a part of an occupational health survey of factory workers. The workers both in production sections and in clerical sections were invited to participate in the study, and sera obtained from 426 workers ( 243 men and 183 women at the ages of 17 to over 50 years) were subjected to the seroepidemiological study.

HBV marker assoys. The radioimmunoassay kits for 3 markers, i.e., AUSTRIA - $11-125$ for HBsAg. AUSA B for Anti-HBs, and ANTI HBc RIAKIT - for Anti-

Received September 9, 1991 ; accepted October 11. 1991.

'Tohoku Rosai Hospital, Sendai, Japan. "Institule of Occupational Medic/ne. Chinese Academy of Preventive Medicine, Beijing. China. "Miyagi Uniwersity of Education, Sendai, Japan. 'Osaka Occupational Health Service Center, Oeaka, Japan. -Deperiment of Public Health. Shandong Medical University, Jinan, Shandong. China. "Department of Public Healih, Kyolo Untvarsity Faculty of Medicine, Kyoto, Japan.

Address for correspondence; Masayuki Ikeda. Department of Public Health, Kyoto University Facully of Medicine. Yoshidakonoe-cho Sakyo-ku. Kyolo 606-01. Japan. 
HBc, were supplied by Abbott Laboratories (North Chicago, IL, U.S.A.). The cut-off indices for the identification of positive cases (to be abbreviated as

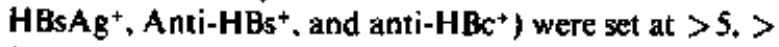
2 . and $>70 \%$, respectively.

Statistical evaluation. Statistical significance of dif. ference in prevalence was evaluated by means of chi- square test.

\section{RESULTS}

\section{Prevalence of the $3 \mathrm{HBV}$ infection markers amang} the study population

The prevalence of cases positive to the three markers are summarized in Tables 1 and 2 . Those positive to

Table 1. Prevalence of hepatitis B virus (HBV) infection markers among factory workers in Yantai,

\begin{tabular}{|c|c|c|c|c|c|}
\hline \multicolumn{3}{|c|}{ HBV infection marker } & \multicolumn{3}{|c|}{ Number of cases } \\
\hline HBsAg & Anti-HBs & Anti-HBc & Men & Women & Sum \\
\hline- & - & - & $64(26.3)$ & $62(33.9)$ & $126(29.6)$ \\
\hline- & + & - & $12(4,9)$ & $4(2.2)$ & $16(3.8)$ \\
\hline- & - & + & $25(10.3)$ & $14(7.7)$ & $39(9.2)$ \\
\hline- & + & + & $79(32.5)$ & $58(31.7)$ & $137(32.2)$ \\
\hline+ & - & - & $27\{11.1\}$ & $24(13.1)$ & $51(21,0)$ \\
\hline+ & + & - & $0(0.0)$ & $0(0.0)$ & $0(0.0)$ \\
\hline+ & - & + & $33(13.6)$ & $19(10.4)$ & $52(12.2)$ \\
\hline+ & + & + & $3(1.2)$ & $2(1 . I)$ & $5(1.2)$ \\
\hline
\end{tabular}

In tolal, 426 adults (243 men and 183 women) were studied. The numbers in the table are the numbers of cuses and the percentages in parentheses. + : Positive. - Negative.

Table 2. Prevalence of $\mathrm{HBsAg}^{+}$, anti-HBs+ and anzi-HBc* cases by age and by sex.

\begin{tabular}{|c|c|c|c|c|c|c|c|}
\hline \multirow{2}{*}{$\begin{array}{l}\text { Age } \\
\text { range } \\
\text { lyedrs\} }\end{array}$} & \multirow{2}{*}{$\begin{array}{l}\text { No. of } \\
\text { sera } \\
\text { lested }\end{array}$} & \multicolumn{5}{|c|}{ Indicative of HBY infection } & \multirow{2}{*}{$\begin{array}{l}\text { HBV } \\
\text { marker } \\
\text { negativer }\end{array}$} \\
\hline & & HBsAg' & Anti-HBs* & Anti-HBc* & $\begin{array}{c}\text { Anti-HBs }{ }^{+} \text {or } \\
\text { Anti-HBc }\end{array}$ & Over-all & \\
\hline \multicolumn{8}{|l|}{ Men } \\
\hline $15-19$ & 16 & $3(18.8)$ & $6(37.5)$ & $9(56.3)$ & $9(56.3)$ & $10\{62.5\}$ & $6(37.5)$ \\
\hline $20-29$ & 168 & St (30.4) & $50(29,8)$ & $92(54.8)$ & 乐 $(57.1)$ & $117(19.6)$ & $51(30.4)$ \\
\hline $30-39$ & 34 & $5(14.7)$ & $2 t(52.9)$ & $18(52.9)$ & $24(70.6)$ & $28\{82.4\}$ & $6(17.6)$ \\
\hline $40-49$ & 18 & $2(11.1)$ & $14(77.8)$ & $16(88.9)$ & $|8| \mid 00.0)$ & $18(100.0)$ & $0(00.0)$ \\
\hline$\geq 50$ & 7 & $2(28.6\}$ & $3(4 \geq 9)$ & $5(7 t .4)$ & $5(71.4)$ & $6\{85.7\}$ & $I(14.3)$ \\
\hline Tatal & 243 & $63(25.9)$ & $94(38.7)$ & $140(57.6)$ & $152(62.6)$ & $179\{73.7\}$ & $64(26.3)$ \\
\hline \multicolumn{8}{|l|}{ Women } \\
\hline $15-19$ & 22 & $7(3) .81$ & $6(27.3)$ & $7(31,8)$ & $8(36.4)$ & $13(59.1)$ & $9(40.9)$ \\
\hline $20-29$ & 86 & $24(27.9)$ & $27(31.4)$ & $38(44.2)$ & $40(46.5)$ & $54(62.8)$ & $32(37.2)$ \\
\hline $30-39$ & 37 & $8(21.6)$ & $15(40.5)$ & $21(56.8)$ & $21(56,8)$ & $25(67.6)$ & $12(32,4)$ \\
\hline $40-49$ & 24 & $4\langle 16.7)$ & $9\{37.5 \mid$ & $16(66.7)$ & $17(70.8)$ & $18(75.0)$ & $6(25.0)$ \\
\hline$\geq 50$ & 14 & $2(14,3)$ & $\tau(50.0)$ & $11(78.6)$ & $11(7 B .6)$ & $11(78.6)$ & $3(21.4)$ \\
\hline Tolal & 183 & $45(24,6)$ & $64\{35.0)$ & $93(\$ 0.8)$ & $97(53.0)$ & $121(66.1)$ & $62(33.9)$ \\
\hline \multicolumn{8}{|c|}{ Men and women combined } \\
\hline $15-19$ & 38 & $10(26.3)$ & $12(31.6)$ & $16\{42.1\}$ & $17(44.7)$ & $23(60.5)$ & $15(39.5)$ \\
\hline $20-29$ & 254 & $75(29.5)$ & $77(27.6)$ & $130(51.2)$ & $136(53.5)$ & $171(67.3)$ & $B 3(32.7)$ \\
\hline $30-39$ & 71 & $13(I B .3)$ & $36(50.7)$ & $39(54.9)$ & $45(63,9)$ & $53(74.6)$ & $18(25.4)$ \\
\hline $40-49$ & 42 & $6(14.3)$ & $23(54,8)$ & $32(76.2)$ & $35(83.3)$ & $36(85.7)$ & $6(14.3)$ \\
\hline$\geqslant 50$ & 21 & $4(19.0)$ & $10(47.6)$ & $16(76.2)$ & $16(76.2)$ & $17(80.9)$ & $4(19.0)$ \\
\hline Total & 426 & $108(25.4)$ & $158(37.1)$ & $233(54,7)$ & $249(58.5)$ & $300(70.4)$ & $126(29.6)$ \\
\hline
\end{tabular}

The values in the table are the number of cases and the percentages in parentheses.

+ : Positive. Positive to either anti-HBs ot anti HBc. Over-all rate of infection as defined by the rate of these positive to any of the 3 markers. " Negative to all of the 3 markers tested. 
HBsAg accounted for one fourth of the population studied with no significant difference in the prevalence between the two sexes $(p>0.10)$, and about a half of the $\mathrm{HBsAg}^{+}$people were negative to the 2 antibody items. In contrast, about one third of the people studied were anti-HBs ${ }^{+}$and anti-HBc ${ }^{+}$in both sexes. and somewhat less than one third was negative to all of the 3 infection markers (Table I). Thus, well over two thirds of the study population were either currently or previously infected with HBV.

Very few (1\%) were positive to all the three markers, as theoretically expected. In such cases, they were very weakly anti-HBs ${ }^{+}$with titers just above the cut-off point, whereas anti-HBc titers were high and $\mathrm{HBsAg}_{8}$ titers were various depending on the cases.

\section{Age-dependent changes in $\mathrm{HBV}$ infection rates}

The observed cases were further classified by sex and by decade of years of ages of the subjects (Table 2). There is a gradual age-dependent decrease in $\mathrm{HBs} \mathbf{A g}^{+}$ prevalence both in men and women, albeit the rate for those at the ages of 19 years or less $(18.8 \%$ for men and $31,8 \%$ for women) may be comparable to that for $20 \mathrm{~s}$; no significant difference in the prevalence was detected between those at less than 20 years of age and those at 20.29 years, when the two sexes were combined $(\mathrm{p}>$ 0.10 ). A high rate of $28.6 \%$ for $>50$ year-old men should be considered not reliable because only 7 subjects were examined.

Both anti-HBs ${ }^{+}$and anti-HBc ${ }^{+}$rates gradually increased in parallel in both sexes as ages advanced, so that about $80 \%$ or more of the population acquirest immunity to $\mathrm{HBV}$ infection at the age of 40 years (i.e., either anti-HBs ${ }^{+}$or anti- $\mathrm{HBc}^{+}$, or anti $\mathrm{HBs}^{+}$and anti$\mathrm{HBC}^{+}$). When positive reaction in any of the three infection markers (i.e., $\mathrm{HBSAg}^{+}$, anti-HBs ${ }^{+}$or anti$\mathrm{HBc}^{+}$) were considered to to be indicative of past or current HBV infection, almost all subjects (more than 85\%) had experienced HBV infection before the age of 50 , whereas less than $15 \%$ of the people remained negative to any of the three HBV infection markers at this stage of life.

\section{DECussion}

The present study of a Yantai population has shown that the rate of those positive to $\mathrm{HBsAg}$ was as high as $25.4 \%$ (25.9\% in men and $24.6 \%$ in women), and that the rate when two sexes were combined was highest (i.e.. $29.5 \%$ ) at the ages of $20 \mathrm{~s}$ followed by gradual decrease at higher ages (about $20 \%$ or less). The overall HBV infection rate as calculated by those positive to any of the three markers studied was $70.4 \%$.

A growing number of papers have been published in recent years to report the prevalence of HBV infection especially in terms of $\mathrm{HBsAg}^{+}$, and in some cases as the positivities to the three infection markers, in various cities and provinces in China ${ }^{5-7,31-18,20-40)}$. The results of the reviewing are summarized in Table 3 . In comparative evaluation of the results in which radioimmunoassay, hemagglutination assay or the both in combination were employed, it should be taken into account that the sensitivity of the two methods vary and that hemagglutination method employed was reported to be less sensitive than the radioimmuno;ssay ${ }^{13,377}$. Nevertheless, it is conceivable from the table that the $\mathrm{HBsAg}^{+}$rate for the present Shandong examinees, 25.4\%, is markedly higher than the values repotted for various provines including Guangxi Province where PHC mortality is known to be very high especially in men'"; the values higher than the present observation are usually associated with known HBV infection ${ }^{2 s)}$ or inclusion of hepatitis cases $^{38 !}$.

The anti-HBs ${ }^{+}$and anti-HBc ${ }^{+}$rates were nol remarkably high so that the over-all rate of HBV infection of the present study population is only comparable to the values for other provinces. It was previously pointed out that the prevalence of $\mathrm{HBV}$ infection is lower in a large city like Beijing (although not in Shnaghai where PHC mortatity is reported to be high "') than in rural provinces' ${ }^{17}$. Simple urban-rural difference, however. will not be sufficient to explain rather unusually high HBsA $B$ rate among the working population in the present study (Tables I and 3 ).

For comparison with the present observation. 6 reports $^{28-351}$ are available in addition to an early report of Beasley and his co-workers" on HBV infection in Shandong Province in particular. The reported HBV infection prevalence as defined by positive to any of the 3 markers reported in recent siudies ${ }^{23-}{ }^{351}$ are in a wide range of $27.4 \%^{343}$ to $78.3 \mathrm{~g}^{353}$. Nevertheless, the prevalence of $\mathrm{HBsAg}^{+}$cases are all well below $10 \%$.

Beasley et al. ${ }^{31}$ found that the $\mathrm{HBsAg}^{+}$preralence among former Shandone Provinte residents currently in Taiwan were 9.3\%, the value being not higher as compared with the values for thuse from northern China (1I.2\% on an average) and probably lower than the values for those from southern China $(17.7 \%)$. In agreement with rather low HBsAg' prevalence, the rates of mortality from liver cancer (per $10^{5}$ population, based on deaths in 1973 to 1975, and age-adjusted to 1964 census population of ('hina'"i) was 11.57 for men (4.24 for women) in Shandong Province: the values ane not higher than the values for the whole country (14.52 for men and 5.61 for wamen), and yuite lower than those for Guangxi Province (26.55 for men and $6.6 \mathrm{~J}$ for women) where $\mathrm{HBV}$ inlection prevalence 
TaNe 3. Comparison of HBV infection marker prevalence in Chinces populations.

\begin{tabular}{|c|c|c|c|c|c|c|c|c|}
\hline \multirow{2}{*}{$\begin{array}{c}\text { Sludy } \\
\text { yreg }\end{array}$} & \multicolumn{2}{|r|}{ Population } & \multirow{2}{*}{$\begin{array}{c}\text { Assmy } \\
\text { by } \\
\mathrm{R} \text { or } \mathrm{H}^{\mathrm{b}}\end{array}$} & \multicolumn{4}{|c|}{ HBV infection marker positive (\%) } & \multirow{2}{*}{ Reference } \\
\hline & No. & Noles & & HBsAg & Anti-HBs & Anti-HBc & Over-alls & \\
\hline Anhui & 503 & Factory workers & $\mathbf{R}$ & 8 & 46 & -4 & 53 & 16 \\
\hline Beijing & 398 & All ages & $\mathbf{R}$ & 7 & - & - & - & 20 \\
\hline ibid. & 600 & Dental workers & H & 6 & 20 & - & 26 & 21 \\
\hline ibid. & 491 & All ages & $\mathbf{R}$ & 7 & 37 & 46 & 52 & 22 \\
\hline thed. & 968 & Fuctory workers & $\mathbf{R}$ & 4 & 37 & 38 & 44 & 17 \\
\hline Fujian & 407 & Children $\{1979\}^{\circ}$ & H & 17 & - & - & - & 23 \\
\hline thid. & 6558 & Children 11987$\}^{\circ}$ & H & 7 & - & - & - & 23 \\
\hline Guandong & 265 & Controls to PHC & $\mathbf{H}$ & 7 & - & - & - & 5 \\
\hline ibot. & 2443 & Male prisoners & $\mathbf{R}$ & 25 & 46 & 20 & 81 & 24 \\
\hline Guangxi & 173 & Controls to PHC & H & 16 & 12 & - & - & 13 \\
\hline itwd. & 1310 & Adults & $\mathbf{H}$ & 15 & 9 & 35 & - & 12 \\
\hline bid. & 35041 & All ages & $\mathbf{H}$ & 13 & 8 & - & - & I] \\
\hline thid. & 49 & Controls to PHC & $\mathbf{R}$ & 11 & 63 & 57 & 88 & 6 \\
\hline ibtd. & 49 & Controls to PHC & $\mathbf{R}$ & 23 & 63 & 57 & 88 & 15 \\
\hline bid. & 11072 & Adults & H & 17 & - & - & - & 7 \\
\hline tbid. & 304 & Adults men & $\mathbf{R}$ & 22 & - & - & - & 14 \\
\hline Hentan & 1064 & All ags & $\mathbf{R}$ & - & 26 & - & - & 25 \\
\hline foid. & 579 & Fytmers* & $\mathbf{R}$ & 32 & 38 & 60 & 79 & 26 \\
\hline Hunan & 3089 & All ages & 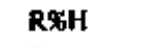 & 18 & 32 & 74 & 81 & 27 \\
\hline Jiangsu & 290 & Factory workers & $\mathbf{R}$ & 9 & 53 & 63 & 72 & 18 \\
\hline Liwoning & 66 & Factory worpers & $\mathbf{R}$ & 8 & 34 & 35 & 48 & 18 \\
\hline Shandong & 926 & Various & $\mathbf{R}$ & 5 & - & - & - & 28 \\
\hline Bhid. & 1367 & All inhabitunts & $\mathbf{H}$ & 7 & - & - & - & 29 \\
\hline sbid. & 436 & All inhabitunts & H & 6 & 10 & 40 & 47 & 30 \\
\hline ibid. & 107 & Controls to PHC & $\mathbf{H}$ & 8 & 55 & 22 & 58 & 31 \\
\hline ibid. & 977 & Farmers & $\mathbf{H}$ & 9 & 19 & 7 & 27 & 32 \\
\hline ibid. & 401 & Clinical staff & $\mathbf{R}$ & 7 & 41 & 68 & 78 & 33 \\
\hline ibid. & 426 & Factory workers & $\mathbf{R}$ & 25 & 37 & 55 & 70 & $\begin{array}{l}\text { Present } \\
\text { study }\end{array}$ \\
\hline Shanghai & 4822 & Adults & H & 10 & 9 & - & - & 34 \\
\hline thid. & 365 & All ages & $\mathbf{R}$ & 7 & 37 & 48 & 57 & 35 \\
\hline tbid. & 520 & Preschool children & $\mathbf{R}$ & 8 & - & - & 22 & 36 \\
\hline ithd. & 290 & & $\mathbf{R}$ & 8 & 48 & 55 & 65 & 18 \\
\hline Shanxi & $\$ 21$ & All agges & ROH & 8 & 23 & 19 & 39 & 37 \\
\hline ibid. & 2122 & All ages" & $\mathbf{R}$ & 36 & 31 & 62 & 78 & 38 \\
\hline bid. & 429 & Fuclory workers & $\mathbf{R}$ & 8 & 40 & 49 & 56 & 18 \\
\hline Sichwan & 423 & Adult blood doners & H & 4 & 85 & - & - & 39 \\
\hline Zhejiatng & 5168 & All ages & $\mathbf{H}$ & 13 & 一 & - & - & 40 \\
\hline
\end{tabular}

- Name of province. except for two cities of Beijing and Shanghai. ' $R$ for radioimmunoassay, and $H$ for hemagglutination ussay. Fver-all rate of infection as defined by the rate of those positive 10 any of the 3 marters. \& Not studied. D J-10 year-old children, saudied in 1979. ' 1-6 year-old children, studied in 1987. I Highly infected with HBV. "316 hepatitis cases are included.

is also high (Table 3). Thus, it could be the case that the HBV infection prevalence is specifically high in the present study population, even though the prevalence may be generally low in Shandong Province; such may be quite probable bearing in mind that Shandong Province has a large population of 80 millions in a large area of $150,000 \mathrm{~km}^{2}$.

The age-dependent changes in $\mathrm{HBsAg}^{+}$prevalence of the present study population in Yantai is depicted in comparison with the counterpart observation in Beijing. Shanghai, Wuxi, Xian and Hefei made by the present study group"l-10) in Figure 1; a high prevalence (33\%) observed in less than 20 year-old subjects in Wuxi may be due to the fact that only a small number of people (15 subjects) were examined in this age group, and therefore not depicted in the figure. It is apparent from Figure 1 that the prevalence in Yantai subjects up to 49 years of age is much higher than their 
Talle 4. HBsAg' prevalence in Shandong Province by ages.

\begin{tabular}{|c|c|c|c|c|c|c|c|c|c|}
\hline \multirow[b]{2}{*}{ Study Region } & \multirow{2}{*}{$\begin{array}{l}\text { No. of } \\
\text { subjects }\end{array}$} & \multicolumn{7}{|c|}{ Age range } & \multirow[b]{2}{*}{ Reference } \\
\hline & & $\begin{array}{c}0 \text { to } \\
9\end{array}$ & $\begin{array}{c}10 \text { to } \\
19\end{array}$ & $\begin{array}{c}20 \text { to } \\
29\end{array}$ & $\begin{array}{c}30 \text { to } \\
39\end{array}$ & $\begin{array}{c}40 \text { to } \\
49\end{array}$ & $\begin{array}{l}50 \& \\
\text { over }\end{array}$ & $\begin{array}{c}\text { All } \\
\text { ages }\end{array}$ & \\
\hline Changue Couniy & 926 & 3.2 & 3.4 & 4.3 & 6.0 & 10.5 & 6.6 & 5.4 & 27 \\
\hline Hujmin County & 1367 & 4.5 & 6.4 & 12.2 & 8.0 & 11.8 & 1.8 & 6.5 & 28 \\
\hline Jinnn City & 436 & 0.0 & 4.4 & 6.9 & 6.0 & 12.2 & 10.6 & 6.2 & 29 \\
\hline Shandong Provincen" " & 107 & & & & & & & 8.4 & 30 \\
\hline Penglai County & 977 & & & & & & & B.6 & 31 \\
\hline Zibo City & 401 & & & & & & & 7.2 & 32 \\
\hline Yantei City & 426 & $-c$ & 26.3 & 29.5 & 18.3 & 14.3 & 19.0 & $25.4^{*}$ & $\begin{array}{l}\text { Pressent } \\
\text { study }\end{array}$ \\
\hline
\end{tabular}

- Significantly different from counterpar values ( $\mathrm{p}<0.0 t)$.

- Break-down dy age is not given. "Hospital patients from the Province. et Not studied.

counterparts in other cities, indicating that HBV infection is endemic among this study population. In addition, the fact that the persistent carrier rate is almost 1.5-fold higher in younger people (those below

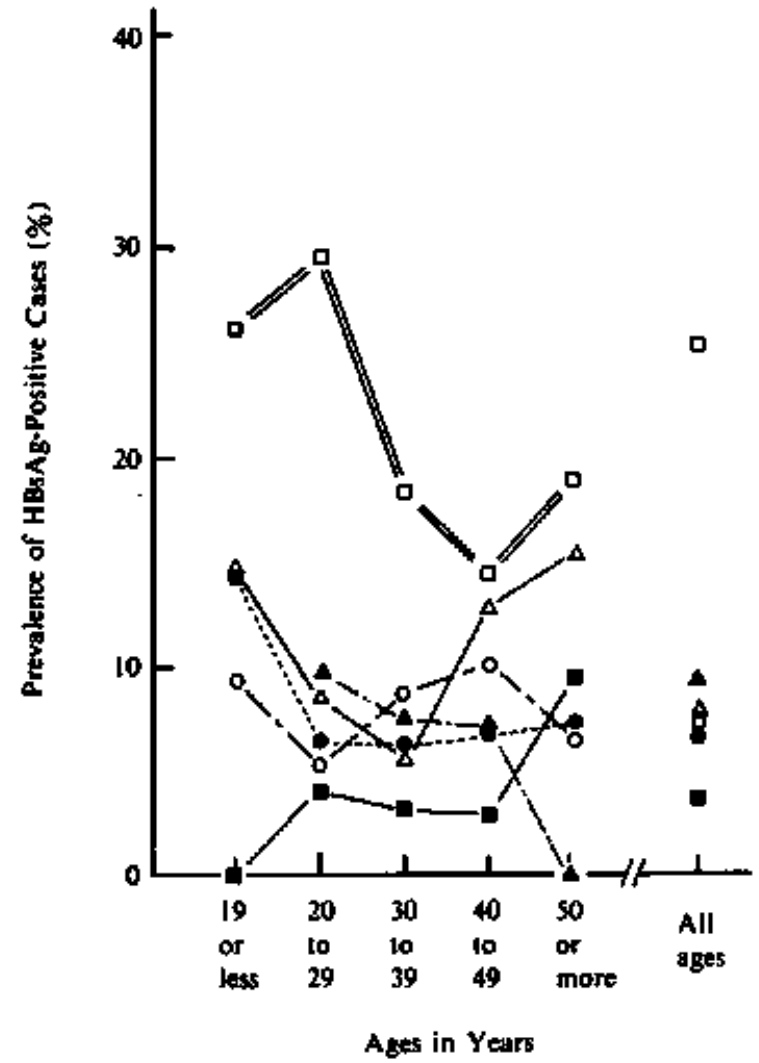

Dgare 1 Agedependent changes in HBsAg+ rate amons peo. ple in Yentai in comparison with those In ather cities.

Rates for two sexes in combination are shown. The values for cities other then Yantai are cited from Sejji at al. ${ }^{16-19)}$. Symbols are; open squares for Yantai, solid squares for Beijing, open triangles for Shanghei, solid triangles for Wuxi, open cireles for $X i a n$, and solid circles for Hefei.
30 years of age) as compared with older people suggest that an unidentified episode might have happened in recent 10-20 years which provoked the increase in the HQV carrier rate. It would be more informative if the rates for younger inhabitants were available.

Several factors have been discussed in explaining the high HBsAg prevalence among various Chinese populations studied. For example, Luo et al. ${ }^{15)}$ considered both vertical transmission from carrier mothers to their new-borme babies and close family contacts during the post-natal period as routes of $\mathrm{HBV}$ infection to produce persistent HBsAg carriers. Tang et al, ${ }^{42}$ examined HBV infection markers of 35 fetuses from $\mathrm{HBs} \mathrm{Ag}^{+}$mothers after induced abortion in comparison with 10 fetuses from HBsAg mothers, and observed that the sign of HBV infection was positive in sera of 7 cases in the former group (20\%) in contrast to none in the latter. In the former group, 12 cases out of 27 liver tissues (44.4\%) were positive to the infection when P-labeled HBV-DNA was employed as a probe, suggesting that intra-uterine infection is also an important mode of HBV transmission ${ }^{22}$, In this connection, it is worthy to note that Duan et al. ${ }^{49}$ in fact succeeded to interrupt mother-to-baby transmission of HBV by the administration of $H B V$ vacsine to the babies born to HBsAg ${ }^{+}$mothers. Regarding the latter possibility, Huan et al. ${ }^{806}$ observed in their epidemiological study of preschool children in Shanghai that the habit of premastication of food to feed children is associated with two-fold higher risk of the infection within a family. Opinions are equivocal among Chinese scientists on possible contribution of allatoxin B contamination of food as a co-sausative factor of PHC in combination with persistent HBV infection, in explaining high PHC incidence among Guangxi inhabitants ${ }^{13,14)}$

A few more reports are available in which trials were made to explain the mode of HBV infection among Chinese inhabitants outside the Continent. In Sin- 
gapore. Quak et al." examined Chinese children for HBV infection in comparison with their counterparts of Malay and Indian origin and found that. although $\mathrm{HBsAg}^{+}$prevalence appeared to be almost comparable among the 3 ethnic groups, the prevalence of anti-HBs ${ }^{+}$ and anli-HBc ${ }^{+}$cases were significantly higher among Chinese children than in Malay or Indian children. In a study of babies born $10 \mathrm{HBsAg}{ }^{+}$mothers in Taiwan, Stevens and others ${ }^{43}$ observed that the risk of babies to be $\mathrm{HBsAg}^{+}$increased when his/her mother had high titer HbsAg, when the umbilical cord blood was $\mathrm{HbsAg}^{+}$, or when his/her sibling was $\mathrm{HbsA}^{+}$, and concluded that the vertical transmission occur rather frequently. In contrast, Lam et al. ${ }^{40)}$ observed a sharp increase in $\mathrm{HBsAg}^{+}$prevalence from first (less than 10\%) toward fourth decade (over 40\%) of life (and then decrease thereafter) among Chinese population in Hongkong, and thought that the dominant mode of HBV transmission among Chinese people there was likely to be horizontal rather than vertical.

At the moment, no plausible explanation is available to understand the unusually high HBV infection prevalence among the population studied. Whether the prevalence is high in Yantai City in general or it is so among the study popularion only is still yet to be elucidated. Careful observation of the local culture and the way of daily life appears to be extremely important in order to identify the social habits which enhance the risk of infection at an early stage of life.

\section{ACKNOWEDGEMENTS}

The authors are grateful to Prof. T. Suzuki, the Director of Tohoku Rosai Hospital, Sendai 980 . Japan, and Prof. $\mathbf{S}$. Horigtchi, the Director of Osaka Occupational Health Service Center, Osaka \$50. Japan for their support to and interesa in this work.

\section{REFERENCES}

I. Nishioku K. Levin AG. Simons MJ. Hepatitits B antigen. antigen subtypes, and hepatitis $B$ antibody in nortal subjects and patients with liver disease. Bull WHO, 1975 ; 52: 293-300.

3. World Healuh Organization: Advances in viral bepatitis. WHO Technical report Series No. 602: $1977: 7-62$.

3. Bessley RP, Lín C-C, Chien C-S, el al. Geographic distribution of HBsAg cartiers in China. Hepatology. $1982 ; 2 ; 554-556$.

4. Brown P. The seroepidemiology of bepatitis $A$ and $B$ in the Asia-Pacific region. Asia-Pacific J Public Health, $1987 ; 1(3): 62-78$.

5. Lu G.P. Chen Q-Z. Relation between the mortalicy of primary hepatic carcinoma and viral hepatitis in the surveillance artas of Jiangmen City. Chinese J Epidemiol, I985; 6 : 241-244. (in Chinese with an English abstract)

6. Yeh F-S. Mo C-C、Henderson BE, et al. A serological case-control study of primary hepatocellular carcinoms in Guangxi, China. Cancer Res. 1985: 45 : 872-873.
7. Ding Z-R, Li R-C, Gong J, a al. Epidemiological study on relationship between hepatitis $\mathrm{a}$ and liver cancer. Chinese J Epidemiol, 1988: 9: 220-223, (in Chinese with an English abstract)

8. Oust ID, Lehmann NI, Dimitrakakis M. A seroepidemiologic sludy of infection with HAV and HBV in five Pacific islands. Am J Epidemiol, 1979; 110; 237-242.

9. Sobeslavsky 0 . Prevalence of markers of hepatilis B virus infection in various countries: a WHO collaborative study. Bull WHO. 1980; 58 : 621-628.

10. Yutu J. Epidemiological studies of viral Heparitis $A$ and $B$ in the People's Republic of China. In : Szmuness W, Alıer HJ and Maytard JE (eds) Vical Hepatitis. Franklin Institute Press, Philadelphia, 1982.

II. Ding Z-R, Li R-C. Distribution of viral hepatitis B n infection in Guangxi Province. Chinese J Epidemiol, 1982; $3: 84-87$. (in Chinese)

12. Xie Y-B, Sperific and nonspecific infection of hepatitis B among population in town center of Lipu County of Guangxi Autonomous Region. Chinese J Epidemiol, 1983; $4: 331-334$. (in Chinese with an English abstract)

13. Ding Z-R, Li R-C. Huang G-Y, a al. Epidemiological analysis of the etiological relationship between primary hepatocarcinoma and hepatitis B virus. Chinese J Epidemiol, 1984 ; 5 : 146-149. fin Chinese with an English abstract)

14. Yeh F-S, Yu MC, Mo C-C. et al, Hepatitis B virus. aflatoxins. and hepatocellular carcinoms in south Guangxi, China. Cancer Res, 1989; 49: 2506-2509.

15. Luo S, Ye F-S, Mo Z-C, a al. Prevalence of hepatitis B viral markers in hepalitis $B$ endemic areas of China. Chinese Med J. 1988: 10I: 654-658.

16. Seiji $K$, Inoue $O$, Kasahara $M$, et al.Prevalence of serological hepatitis $B$ markers in a working population in Hefei, China. Asia-Pacific J Public Health, 1987; 1(4): 28-33.

17. Seiji K. Inowe O. Liu S-J, et al. Prevalence of hepatitis B virus infection markers umong factory workers in Bejjing. China. Asia-Pacific J Public Healah, in press, $1991 \mathrm{la}$.

18. Seiji $K$, Inoue 0, watanabe $M$, et al, Heparitis B virus prevalence in industrialized cities in China. Asia-Paxific J Public Health, in press, 1991b.

19. Lee S-H, Lee B-K, Lee K-M, et ul. Hepatitis B vitus infection among women in a shoe factory in korea. Asia-Pacific J Public Healih. 1989 ; 1 : 145-149.

20. Wang H-T, Jiang Y-T, Ma J, et al. Some characteristics of cbronic carriers of hepatitis B surface antigen. Chinese J Prev Med. 1984: 18 : 334-336. (in Chinese with an English abstruct)

21. Zhang R-D. Zhao Y. Tao J-M, et al. Survey of hepatitis B virus infection in dental workers. Chinese J Stomatol. 1982: 17: 137-139. (in Chinese)

22. Wang H-T. Jiang Y-T, Ma J, et al. Seroepidemiologic study of viral hepatius $B$ in a suburb of Beijing. Chinese J Epidemiol, 1985; 6 : 141-144. (in Chinese with an English abstrace)

23. Zeng S-J, Yang W-C. Huang J-Z. A study of children with HBsAg markets related to their parent's HBV markers. Chinese J Epidemiol, 1990: 11: 338-340 (in Chinese with an English abstract)

24. Lu Q-S, Lue K-X, Zhu H-Q, et al. A prospective serological epidemiological investigation of hepatitis B virus infection in a prison. Chinese J Epidemiol. 1990: II : 267-270. (in Chinese with an English abstract)

25. Kau P.Y. Distribution of antibody against HEs among 
people in Henan Province. Chinese J Epidemiol, 1984: 5: 14-15, din Chinese with an English abstract)

26. Tan H-Z, Xiao Y-J. Wu P.L. at at. Family elustering amalysis of HBV infection. Chinese J Prev Med. 1989: 23: 135-138. (in Chinese with an English abstract)

27. Xío Y-J, Tan X-M. Tan S-L, Yang T-B. Seroepidemiological study of HBV infection in Hunan area. Chinese J Epidemiol, 1990; 11 : 133-137. (in Chinese with an Englisb abstract)

28. Yu J-Y, Xiu Y-Y, Liu T-X, Fan $Y-X$. Prevalence of HBs Az-positive cases. Weisheng Fangyi iJ Hyg Prev Epidem) 1984; No. 13: 17-19. (in Chinese)

29. Li L. Prevalence of HBsAg-positive cases in Huimin County region. Shandong Weisheng Fangyi (Shandong J Hys Pev Epidem) 1984; 4; (9-20. (in Chinese)

30. Lj L, Shen M-H. Peng Y-F, et al. An investigation on infective markers of HBV among natural population in Jinan. J Shandong Med Univ 1985: $23:$ 13-17. (Chintse with an English ybstract)

3I. Li L, Jiang B-F, Wang Y-J, Feng Y-Q. Detection of IgM anti-HBc in patients with primary hepalic carcinoma. Chinese J Epidemiol 1987; 5: 25-27. (in Chinese with an English abstract)

32. Yu L-M. Zhang Y-D. Ji Y-J, et al. Seroepidemiological study on HBY infection in Penglai County region in Shandong Province. Shandong Weisheng Fangyi (Shandong J Hyg Prev Epidem) 1987: 7: 29 only. (in Chinese)

33. Feng $M-L$. Survey on HBV infection markers among clinical staff. Shandong Weisheng Fangyi (Shandong J Hyg Prev Med) 1989; $9: 64-65$. (in Chinese)

34. Gu B-C, Gao R-N, Wu Y-J, et al. Comparison of the presence or absence of early hepatitis $B$ viral infections among populations in afeas with high and low incidences of primary hepatoma. Chinese J Epidemiol, 1983:4: 37-42. (in Chinese with an English abstratt)

35. Hu M, Schenzle D, Deinhardt F, Scheid R. Epidemiology of hepatitis $A$ and $B$ in the Shanghai area: Prevalence of serum markers. Am J Epidemiol, 1984 ; 120 : 404-413.

36. Huan M-J, Xu Z-Y, Fu T-Y, Zhou D-K, An epidemiological study on prevalence and risk factors of heputitis B virus (HBV) infection in preschool children. Chinese J Epidemiol. 1990; 11 : 129-132. (in Chinese with an English abstruct]

37. Mi E-Y, Zhane F-K, Liu Y-P, Lu T-L, Seroepidemiological study of hepaticis B virus infection in rural ureas of Shanxi Province. Chinese J epidemiol, 1984:5: 325-328. (in Chinese with an English abstract)

38. Lin $Y$-H, Yan X-E, Liv $X-L$, et al. SPRIA assays on HBV in 2122 out- and in-patients and RPHA assays on HBsAg in 5872 cases. J Shanxi Province Peoplets Hospital. 1989; $2: 30-34$. din Chinese)

39. Jia W-X, Mu J-W, Cai M-Y, et al. Studies on distribution of HBV infection in voluntary blood donors. I West China Univ Med Sci, 1986; 17; 277-279, lin Chinese with an English abstract!

40. Zhung Z-H, Ge L-Q. Investigation on human carriage of HBs Ag in Qingtian County. Chinese J Epidemiol, 1983 ; 4: 79-82, lin (hinese with un English abstract)

41. Editorial Committec for the Atlas of Cancer Mortality in the People's republic of China. Atlas of Cancer Mortality in the People's republic of China, China Map Press. Shanghai, 1979 .

42. Tang S-X. Yu G-L, Cheng S-Y. Study on the HBV intrautrine infection and its rate. Chinese J Epidemiol. 1990: 11 : 328-330 (in Chinese with an English abstract)

43. Duan S-C, Xu Z-Y, Zhu Q-R, et al, Interruption of materno-infantile transmission of HBV by $\mathrm{HBV}$ vaccine. Acta Paediat Jpn 1989; 31 : 649-653.

44. Quak SH. Singh R, Con CJ, Wong HB. Across-sectional study of hepatitis B immune stalus in Asian children in Singapore. Ann Trap Pediat. 1982: 2 : 53-56.

45. Slevens CE, Beasley RP, Tsui J, Le W-C. Vertical transmission of bepatitis $B$ antigen in Taiwan. New Engl J Med 1975: $292: 771-774$.

46. Lam KC, Yuen P, Colbourne MJ, al al. HBV markers in Chinese in Hong Kong. Ann Acad. Med. Singapore. I980: 9 : |49-15I. 